\title{
Standard techniques for formalin-fixed paraffin-embedded tissue: A Pathologist's perspective
}

\author{
H.B. Al-Sabawy ${ }^{\mathbb{D}}$, A.M. Rahawi ${ }^{\circledR}$ and S.S. Al-Mahmood \\ Department of Pathology and Poultry Diseases, College of Veterinary Medicine, University of Mosul, Mosul, Iraq
}

\begin{tabular}{l} 
Article information \\
\hline Article history: \\
Received October 18, 2021 \\
Accepted December 01, 2021 \\
Available online December 11,2021 \\
\hline Keywords: \\
Histopathology \\
Formalin \\
Paraffin \\
Hematoxylin \\
Eosin
\end{tabular}

Correspondence:

S.S. Al-Mahmood

dr.saevan981@gmail.com

\begin{abstract}
Histopathology considered as an eśsential keystone to understanding diseases on a cellular level, without examining affected tissues and cells; will lack the accurate diagnosis. The most common protocol that used worldwide for histopathology is termed as formalinfixed paraffin-embedded techniques; this protocol is the oldest protocol and still used, this technique not invented once, but it is started with a simple process of tissue fixation then undergo several successfal steps as it's known today. This protocol depends on formalin to induce tissue fixation and preservation simultaneously, followed by a series of steps to facilitate infiltration of hot paraffin wax in the cells to adjust the density of tissue similar to that of paraffin wax to support tissue during sectioning process at few micrometers of thickness. Many protocols have been invented and modified subsequently to increase the accuracy of tissue processing and facilitate their study under light microscopy. Additionally, the formalin-fixed and paraffin-embedded samples can be considered the most durable process till now. In this review, we are trying to view all fundamental aspects of classical tissue processing that was depended since 1850 s, starting from tissue examination, sampling, accessory, labelling, fixation, dehydration, clearance, infiltration, and embedding with hot paraffin wax. Additionally, explain the routine sectioning and staining with classical Hari's hematoxylin and alcoholic eosin staining protocol.
\end{abstract}

DOI: $10.33899 /$ ijvs.2021.131918.2023, (CAuthors, 2021, College of Veterinary Medicine, University of Mosul.

This is an open access article under the CC BY 4.0 license (http://creativecommons.org/licenses/by/4.0/).

\section{Introduction}

Pathology is a term refers to the study of disease and lesions observed by naked eye on affected body organs (gross pathology), moreover, pathology deals with lesions and changes that gecur in the tissues and cells by using microscope, which termed in histopathology as (microscopic pathology) (1). There is no big bang start for pathology; instead, started studying the causes of diseases and their manifestation in body organs during the Islamic era in the middles east and the Italian Renaissance in Europe, which could considered as the first practices in pathology (2), in contrast, the first observation and studies was applied by Rudolph Virchow, which makes him the spiritual father of microscopic pathology, Virchow considered the first scientist that hypothesis the lesions appears on body organs could be seen at the cellular level as well by using the microscope that invented a century earlier by Antony van Levenhok (3). The scientist Julius Cohnheim combined both normal tissue protocol in histology histology with their study of the experimental induction of inflammatory process., which can be considered the first practices in histopathology; Cohnheim invented the procedures and protocols for frozen sectioning as well (4).

During the $19^{\text {th }}$-century, molecular pathology immunohistochemistry and electron microscopy were created and widely applied on scientific bases; these new techniques and protocols helped scientists to study diseases at the cellular and molecular levels (5-10). 


\section{Sample grossing and accessory}

Tissue grossing by a naked eyes or combined are used with glass magnifier to describe lesions observed on tissue surfaces and parenchyma, these gross lesions can help pathologist and technician in successive steps to conduct their work efficiently, also grossing process extend to include slicing tissues to choose the represented samples that undergo processing (11). The main action of tissue grossing is to determine the tissue processing protocol, which will be used in the following steps, in addition to providing the technician an initial idea about the fixative that might use to fix tissues, also tissue grossing acts as an assistant to pathologist by describing the gross lesions that appear on the tissues, these lesions help in the final diagnosis of pathological changes (12).

The grossing process sometimes partners with many preprocessing errors, such as management errors that related to sample labelling missing identification documents, and mixing tissue samples from different sources, on the other hand technical errors represented by sampling of normal tissue, advising the wrong fixative, and insufficient gross lesions recording (13). To eliminate these errors during tissue grossing, a set of instructions should be reliant on the technician, such as matching the information in documents with the samples labelling, keeping the label all over the process, monitoring one piece at each time to reduce chances of tissue mixing with cleaning and washing tools after each group of related sample grossing, more over tissue containers should be sealed tightly and cassettes also, accurate labelling to each sample is mandatory required, timing is an important factor, receiving samples and grossing should up to one hoùr at room temperature and less than 6 hours at cooling condition; besides, the technician should reject any sample that didn't has the sufficient documentations eyen the labelling codes (14).

Samples labelling consider the essential step in tissue processing for histopathology; without this step, samples will be mixed, which lead to wrong diagnosis and technical errors (15). Different labelling techniqués and coding system were invented and defended by global laboratories and scientists, but the most critical issues that should take in consideration are the novelty of coding system and specificity of each label uséd, these two keys role in tissue labelling can be applied by through specific identifier numbers and letter that not exceeding two letters and three number by either continuously or intermittently patterns (16). A modern labelling and coding system were applying after digitalizing and automate tissue processing, this new system composes from QR codes that printed previously on tissue cassettes and containers which refers to all process steps to specific received tissue sample, this system has its limitations due to the costs of equipment required for this process, however, it is the accurate system with zero errors (17-19) (Figure 1).

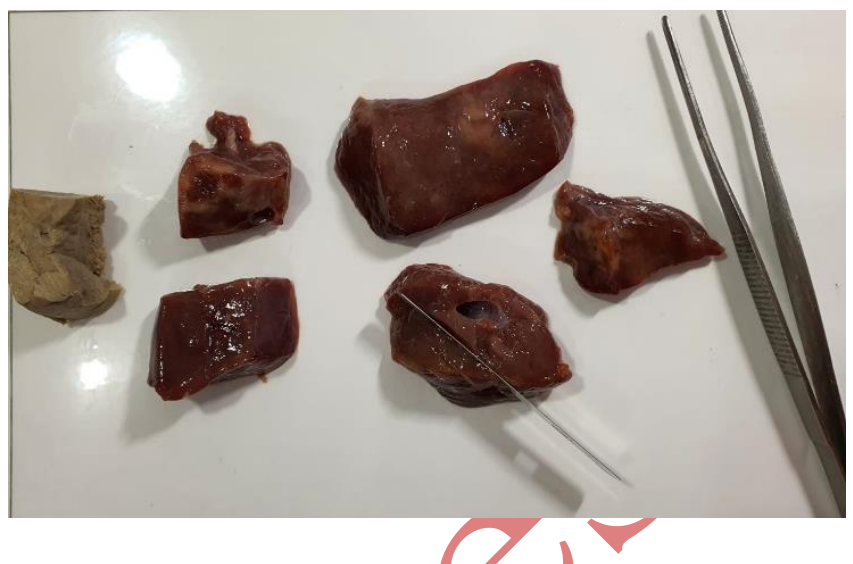

Figure 1: Samples grossing for both formalin-fixed and fresh tissue samples.

\section{Tissue sampling}

After grossing the tissue sample, sliced into small pieces between 0.5 to $1 \mathrm{~cm}$ in thickness, these small pieces of tissue should contain the lesions that was observed in tissue grossing. During this step the technician should take attention to not split the lesion into two tissue samples except the large lesions that can't be included in the same tissue cassette (20).

After these primary cuts, a more accurate trim with secondary cuts should be applied to remove parts of tissue that do not have any effect on pathology analyses, this trim helps in finalizing the shape of tissue samples and produce a regulate shape and size, alter each tissue slice should be upload into a tissue cassette with the accurate labelling (21).

In neoplastic tissue samples, edge inking should be applied with different coloring densities to enable the pathologist to identify the tumor's extent behind these colored edges (22) (Figure 2).

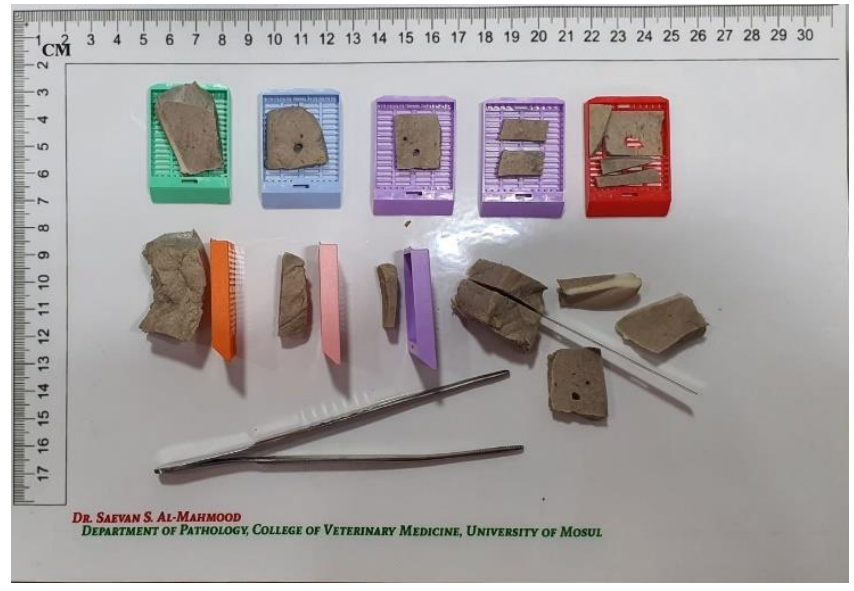

Figure 2: Tissue sampling, the purple cassettes contains the perfect thickness and dimensions for perfect sampling, while other colored cassettes show unappreciated sampling. 


\section{Tissue fixation}

Tissue fixations consider the keystone for preserving biological samples, and the fixative is the tools that used to get rigid tissue fixation be completed; fixation and fixative are used mainly to stop tissue decomposition and decays that are either caused by the action of saprophytic bacteria or by the act of proteolytic enzymes in the cell (23). Fixation, in our opinion, is considered the critical stage in tissue processing since it stops postmortem changes and prevents further biochemical activity in the cell. In addition, the next steps rely on it for being accurate and correct (24). Formaldehyde is considered the gold solution in the fixation process. Butlerov discovered it in 1859 , it is widely used all over the globe to preserve and fix tissues for a long time, named as the classical fixative (25). The ideal fixative solution should have a remarkable ability to penetrate the tissue within a short time, a fewer tissue damages during tissue penetration, and act as both fixative and preservative at the same time (26). Few fixatives could fix and preserve tissue; $10 \%$ formaldehyde (Table 1) considered the best one of these fixatives; others could fix the tissue, but they cause tissue damage during the long exposure time since they are not suitable as a preservative, Bouin's solution is the best examples for this type of these fixatives (Table 2) (27). In general, tissue fixative can be applied in four main methods such as heat, microwave, perfusion, and by immersion; the last method is the most common and widely used protocol since all tissue samples are delivered either from the surgical operation of from postmortem examination (27). Many factors play a role in the action of the fixative solution, such as temperature, osmolality, size and thickness of the sample, the volume of fixative, the $\mathrm{pH}$ of the fixative buffer, fixation time, and concentration fixative (28). Tissue fixation uses a chemical solution such as formalin can be considered a chemical reaction since tissue fixation occurs by one of these three mechanisms: fixation by covalent bond, fixation by protein coagulation, and fixation by forming precipitates formalin considered as a covalent bond fixative (29). Protein fixation by formalin done by two steps; the first one called fast step and starts by forming a covalent bonds with amine groups in amino acids (especially lysine, arginine, tyrosine, histidine, glutamine, and serine) within first 12 hours, later the slow step starts by reaction of glycol methyl groups with each other by methylene bridges [- $\left.\mathrm{CH}_{2}-\right]$ to connect two proteins molecule together(30), while the nucleic acid fixed by formalin through the action of methyl glycol groups that bind to free amino groups in the nucleic acid chains causing fixation of these chains, on other hand the lipoproteins fixed by formalin via the action of methyl glycol groups that produced from the hydrolysis of formalin and bind to carbon particles or Sulphur groups [-SH] recent in these compounds this will cause fixation of lipoproteins, in contrast, formalin did not react or fix the carbohydrate specially long chains from glucose because they consider as chemically inactive compounds and trapped in the other fixed cellular compounds. They fixed by methyl glycol groups (31) (Figure $3,4)$.

Table 1: 10\% Neutral buffered formalin fixative

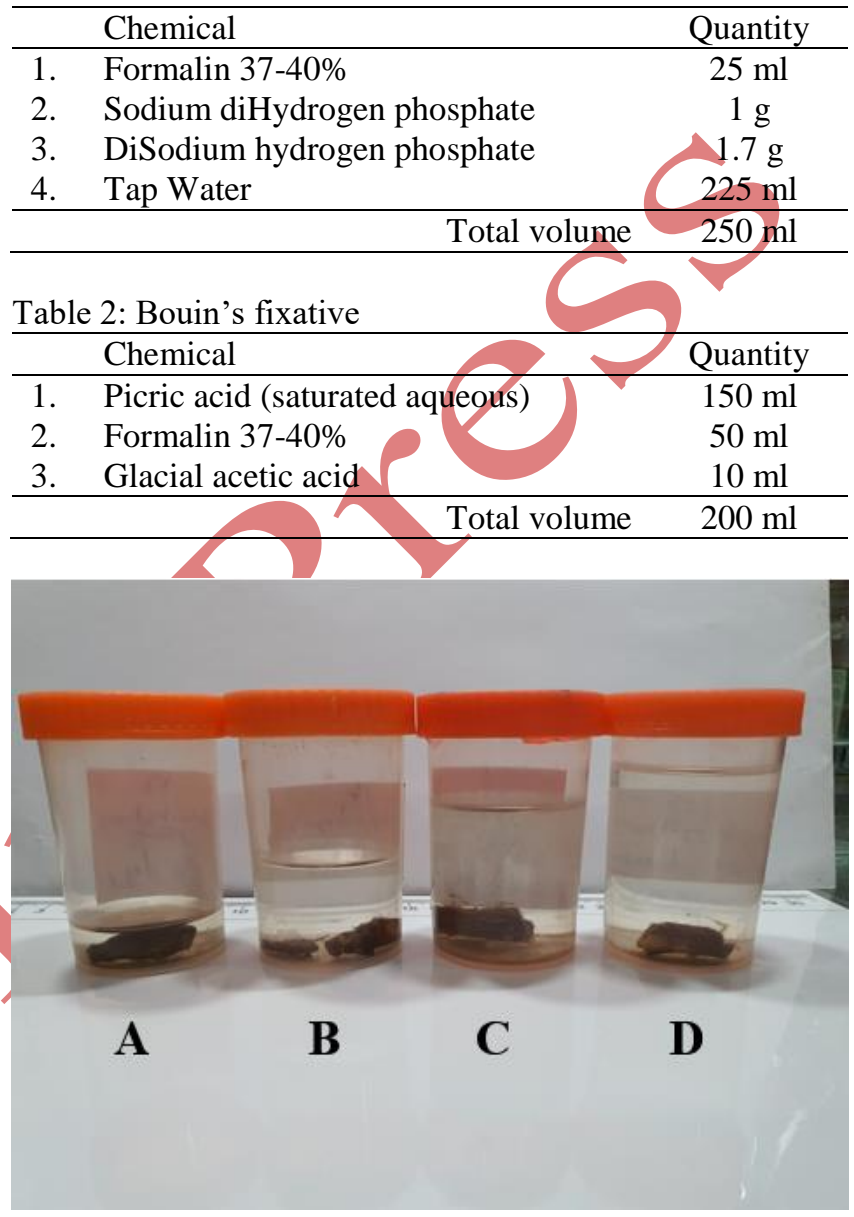

Figure 3: Tissue fixation, container $\mathrm{A}$ and $\mathrm{B}$ have inadequate fixative solution, while the container $\mathrm{C}$ have the appreciated volume of fixative, while the container $\mathrm{D}$ have the perfect volume of fixative to tissue ratio.

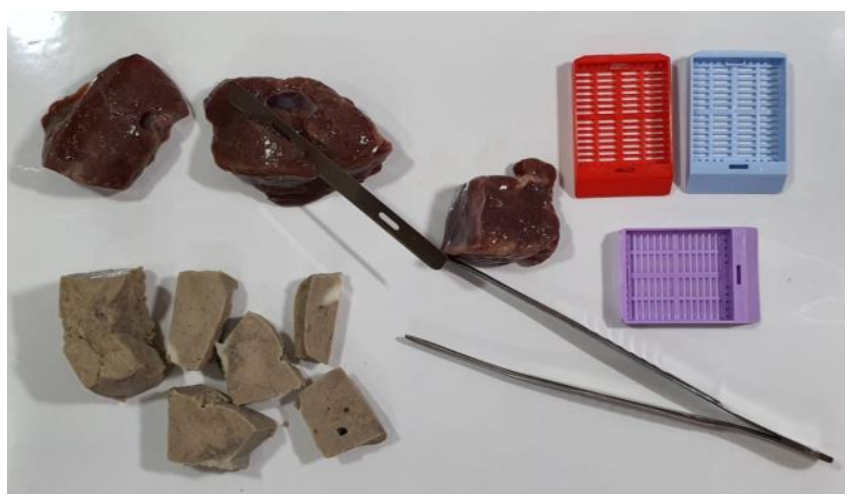

Figure 4: Tissue fixation the differences between fixed and fresh tissues of liver. 


\section{Tissue dehydration}

The principal role of tissue dehydration is to retract the water and other water-based solutions from tissues and cells that fixed with aqueous fixatives because the embedding media is non-aqueous paraffin wax (32). Many solutions can be used to achieve this step, such as ethyl alcohol, acetone, and other methylamine group solutions can be used, but ethyl alcohol is the most preferable and widely used since it is miscible with formalin based fixatives, alcohol acts and penetrates tissue rapidly and starts replacing water with its molecules, during this process the tissue usually will be shrinkage and this incorporated with hardening in the textures of tissue, since that the accurate timing and duration of dehydration period is necessarily required (33). To induce smooth dehydration, gradual water withdrawal should be applied to prevent mechanical damage that caused by rapid dehydration, and this used by immersion of tissue samples into ascending incremental concentrations of ethyl alcohol; $70 \%$ ethyl alcohol is the best concentration as starting point. The dehydration process with $80 \%, 90 \%$ and $100 \%$ is the best procedure for tissue dehydration (34). Ethyl alcohol has many advantages over other dehydration agents since it is miscible with water and induces perfect water withdrawal even in small amounts, also, cause tissue shrinkage and hardening if smooth dehydration completed, which more efficient to all types of tissues, on the other hand, ethyl alcohol has the disadvantage that can be easily overcome, which is toxic, flammable, and cause hardening of tissue if samples were resides for a long time in higher ethyl alcohol concentrations (35). The inadequate dehydration process will produce soft tissues that did not reach the harden enough to be section. The water will not permit paraffin wax to enter the tissues to cause tissue softening and fragile, then resultin tearing of tissue during sectioning (36).

Table 3: The most commonly used clearing agent and their advantage and disadvantages

\begin{tabular}{|c|c|c|}
\hline Agents & Advantages & Disadvantages \\
\hline Xylene & $\begin{array}{l}\text { yery rapid clearing, cheap, and eliminate in the } \\
\text { paraffin }\end{array}$ & $\begin{array}{l}\text { Prolonged treatment induce tissue with quite } \\
\text { brittle }\end{array}$ \\
\hline Benzene & $\begin{array}{c}\text { rates the tissues rapidly, with minimal } \\
\text { shrinking }\end{array}$ & Carcinogen and flammable liquid \\
\hline Chloro & $\begin{array}{l}\text { They were widely used for their hardening effect, } \\
\text { ideal for bone and the brain }\end{array}$ & $\begin{array}{c}\text { Slower than other clearing agents and cause } \\
\text { faintness if inhaled }\end{array}$ \\
\hline Toluene & $\begin{array}{l}\text { Tissues can be kept for a more extended period, } \\
\text { and it is similar to benzene }\end{array}$ & Causes irritation to the skin or eyes \\
\hline Cedar Oil & It has a gentle action on the tissues & Very expensive \\
\hline
\end{tabular}

\section{Tissue infiltration}

Hot paraffin wax at $56-58^{\circ} \mathrm{C}$ was used at this step. Paraffin wax is miscible in xylene; xylene facilitates infiltration of paraffin wax into cells harden it as paraffin wax (44). Other substantial of paraffin wax were used, such as paraplast that contains polymer with Dimethyl sulfoxide,

\section{Tissue clearance}

Tissue clearance is the step that followed the tissue dehydration. The main function is to retract the dehydration residues, especially alcohol and other solutions to solve the embedding media and be miscible (37). The main idea is represented by infiltrating the paraffin wax into tissues and cells; this can't be done directly because the water and alcohol were immiscible with paraffin wax since these solutions should be replaced by another one that was miscible with paraffin wax and can be easily removed and replaced by paraffin wax, xylene is the most commonly used clearing agent (38), in addition to facilitate paraffin wax infiltration the clearing process helps in increase the reflecting index of cells which again facilitate the viewing and observing cellular components (39).

Many clearing agents were used and applied during the clearing step, such as xylene, chloroform, cider wood oil, benzene, clover oil, carbon tetrachloride, and toluene (40). To address a simple comparison between these clearing agents (Table 3), explains the advantages and disadvantages of these clearing agents (41). One of the most common errors were associated with clearing steps with lipids in cells and tissues; these chemical components were dissolved by these agents, especially xylene, leave space inside tissue with different shapes and sizes (42).

The mode of action of clearing agent is related to change the reflecting index to cellular components and increase them to facilitate observing cells by microscopy, as known, cells composed of different types of chemical elements with a different reflecting index each. Although when light wave tries to gross them, they reflect randomly and produce an opaque appearance mainly by water and liquids in cells (43) (Figure 5). 
composed of a mixture of n-alkanes (straight chains) in addition to a carbon chain consisting of 20 to 40 carbon molecules, this type of paraffin is solid at room temperature and have melting temperatures up to $70^{\circ} \mathrm{C}$, a wide variety of paraffin wax is used in histopathology depending upon melting temperature, the best for practical application should have a melting point between $55-58^{\circ} \mathrm{C}(46)$. The viscosity of the melted paraffin wax is a critical point; the best consistency can be obtained by increase the temperature of wax about $2^{\circ} \mathrm{C}$ over the melting temperature, this will allow paraffin wax to infiltrate into tissues, the paraffin wax viscosity is temperature dependent, the technician should be paying attention to not increase the temperature of paraffin wax too much which might cause hardening of the samples and ruin the tissues (47).

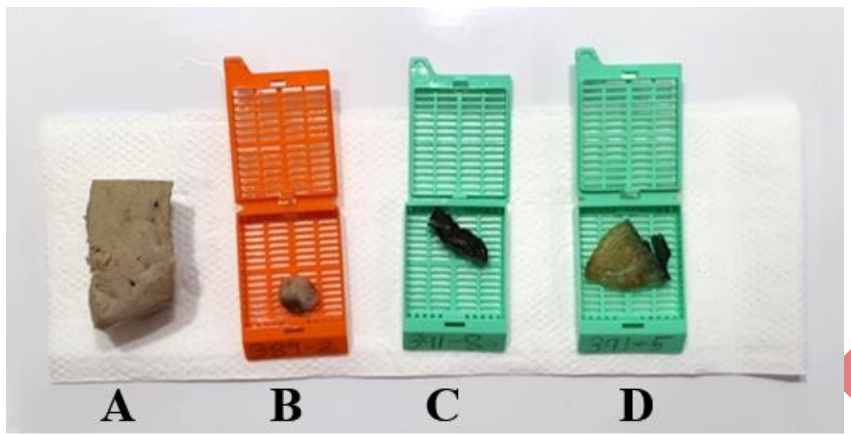

Figure 5: Tissue clearance, A represent complete dehydrated sample, B shows incomplete clearances, $\mathrm{C}$ shows moderate clearing process, while D sample shows complete clearing tissue.

\section{Tissue embedding}

After proper infiltration time in hot paraffin wax, the tissue samples were embedded in cassettes either made from plastic or metals, which gives the final shape that will be sectioned in the next steps; the embedding media in this process is also hot melted paraffin wax, the essential point is the temperature of paraffin wax, which must monitor al time and not exceed $58^{\circ} \mathrm{C}$ because embedding tissues in hot wax will cause crumbling and tearing of tissue sections (48). During this step, the tissue surface should face the bottom of the paraffin mould; then the cassette back cover should attach to the top surface of the paraffin mould, after that a sufficient amount of hot paraffin wax can be added to cover the bottom of the cassette (49). The orientation of tissue samples is such an essential key point during this process, since the lesions can be found at one side of samples; so, the technician should pay attention to adjust the tissue a little bit far from paraffin mould edges at least $3 \mathrm{~mm}$ to allow the formation and accurate paraffin ribbon (50). After embedding, paraffin mould should have cooled at $4^{\circ} \mathrm{C}$ in the refrigerator 30 minutes' minimum to permit paraffin wax to be solid; tissue sample should be removed from paraffin wax and collected for sectioned later (51). This step has many aims to be achieved; the most critical purpose is to give the tissue the supporting background during sectioning for perfect cutting and preserve the morphology of cells and tissue (52) (Figure 6).

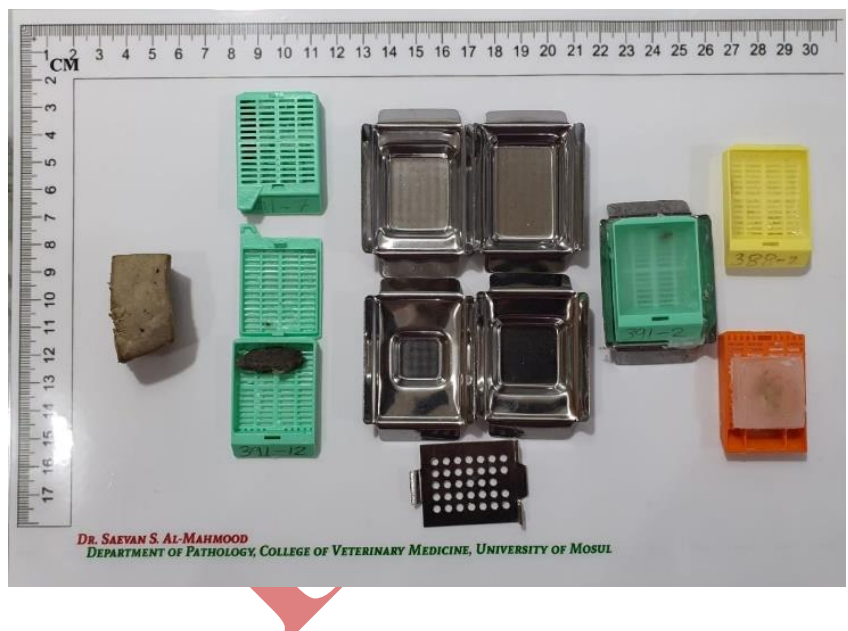

Figure 6: Tissue blocking, shows the different stages of blocking after tissue infiltration with hot paraffin wax.

\section{Tissue sectioning, floatation, lifting and attaching}

Tissue sectioning is the most crucial step after embedding in paraffin, since the accurate section will induce a perfect paraffin ribbon that includes the tissue sample; since the section of the animal tissue depends on cell thickness, the sectioning thickness should not exceed $6 \mu \mathrm{m}$ to be used in routine staining, on the other hand, the section thickness can be reached up to $12 \mu \mathrm{m}$ if chemical tissue staining or special staining protocol used (53). In this process, the most critical instrument that used is the microtome, which can be either sliding or rotary; the last one was worldwide in all laboratories, which was invented during the 1750s and primarily used for plant tissue sectioning then introduced to be used after improving to sectioning the animal's tissues (54). The rotary microtome of two types whether fully automated or semi-automated, this depends upon using of electricity to section the tissue without human interferes which is considered as fully automated, while the semiautomated technician has significant control over the sectioning process except to the thickness of section where it is determined by the mechanical phase used within microtome (55). After a complete paraffin ribbon introduced, the sections floated into a hot water bath at $40-44^{\circ} \mathrm{C}$, allow the cracks to be opened and to reduce and eliminate the folding in sectioned tissues; in some advanced cases, a surfactant could be added to the water of floating to enhance and accelerate the de-folding of the tissues, such as ethyl alcohol, soap and sodium monobasic salts, in addition, tissue attaching improve materials can also be added to the flotation water such as glycerol and gelatin to enhance and fasten the 
securing of tissue to the glass slides, other techniques such as thermal attaching applied by the heating slider to $60^{\circ} \mathrm{C}$ for a least 15 minutes that allow firm linking of tissues to slides (56) (Figures 7-9).

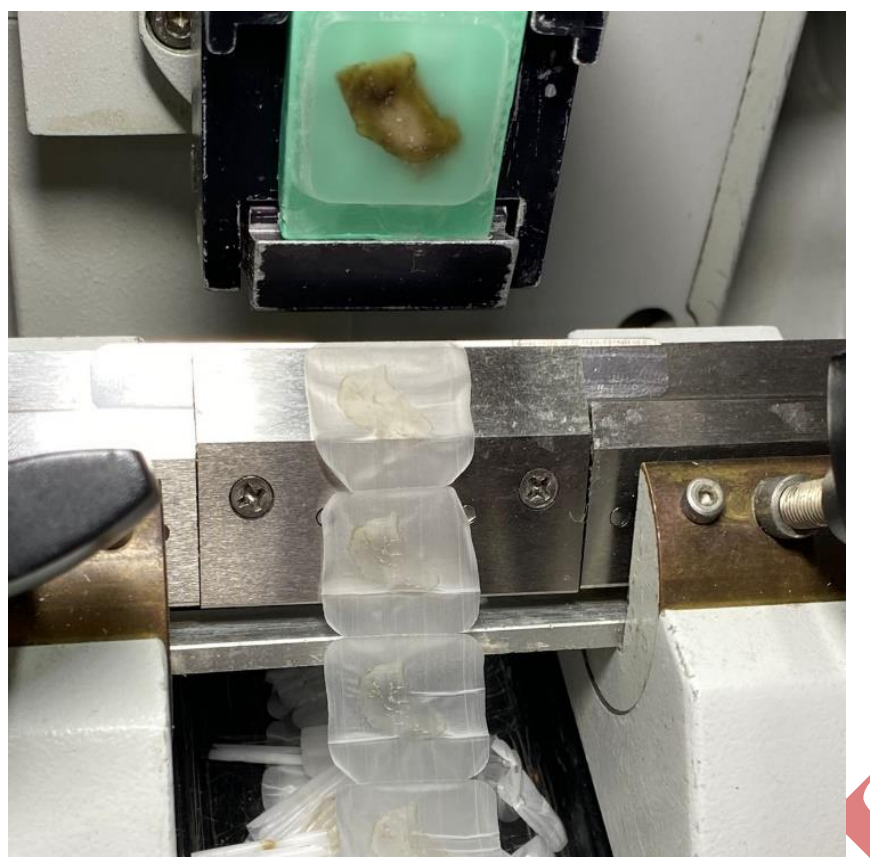

Figure 7: Tissue sectioning and paraffin ribbon formation.

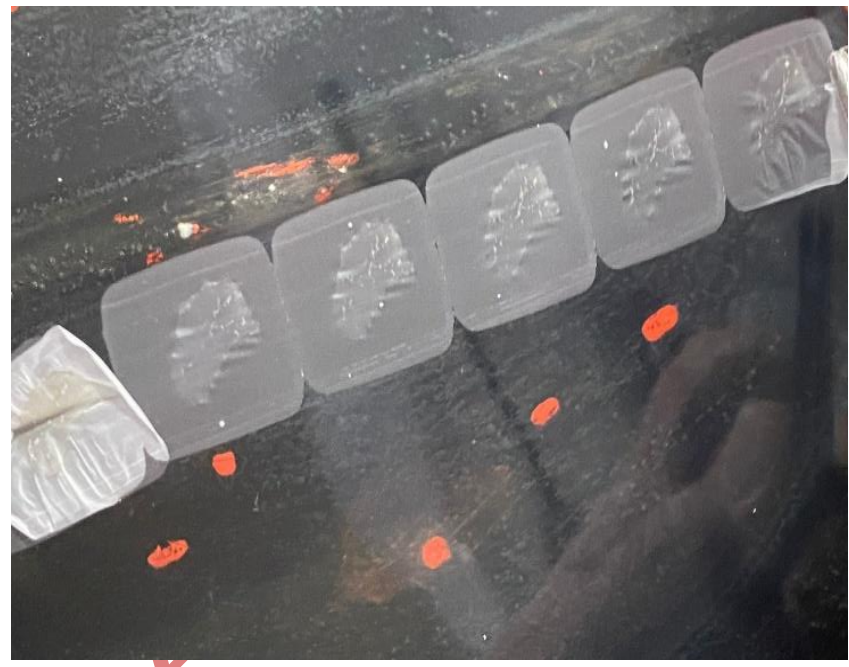

Figure 8: Tissue flotation and sectioning in hot distilled water.

\section{Routine hematoxylin and eosin staining protocols}

Routine staining for animal's tissues depend on a series of continuous steps that ended by red, blue and their shadows staining of different tissue elements that will help in recognizing the components of cells, in which the basophilic parts have the blue coloration as a result of Hematoxylin stain (mainly nucleus and genetic materials), while the acidophilic components have the red coloration caused by Eosin stain (mainly cytoplasm and cell membrane) (57).

The most commonly used hematoxylin was obtained from heartwood from log trees that have a great affinity after oxidization to produce a blue color, with chemical formula $\mathrm{C}_{16} \mathrm{H}_{14} \mathrm{O}_{6}$, which is also used to stain textiles and fabrics coloration for human clothes, also used in writing as blue to black ink, later it is used in histology and histopathology since the 1860s (58).

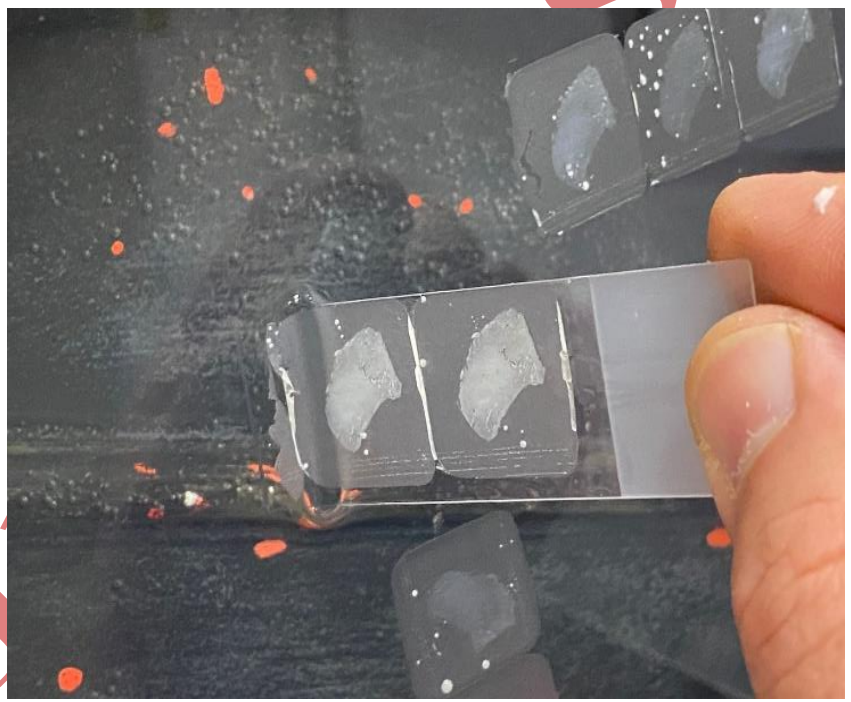

Figure 9: Tissue lifting from flotation water bath.

Hematoxylin staining protocols have many types depend on the mordent that used, which either alum, potassium permanganate, iron, phosphoric acids, and sulphate mordant, in which the potassium and aluminum alum frequently used in laboratories, either aggressive hematoxylins such as Harris's hematoxylin or progressive hematoxylin such as Mayer's hematoxylin, mainly were used and depend on the previous technician experiences with these procedures (59).

The eosin with chemical formula $\mathrm{C}_{20} \mathrm{H}_{6} \mathrm{Br}_{4} \mathrm{Na}_{2} \mathrm{O}_{5}$ considered the red counterstain for hematoxylin, firstly introduced by Heinrich Caro, later many modifications and inventions were applied to ended by design the eosin Y, which is regarded as the best counterstain for hematoxylin in routine staining protocols all over the world, in addition staining cytoplasm eosin also stains muscles and fibers within the tissue (60).

In general, routine alum hematoxylin and alcoholic eosin depend upon introducing blue color by chemical binding of alum hematite with portentous materials that contain arginine in their components such as histone that present in the nucleic acids, while the chemical binding introduces the red color between the bromine with amino acid saturated with lysine and arginine (61) (Figures 10,11). 


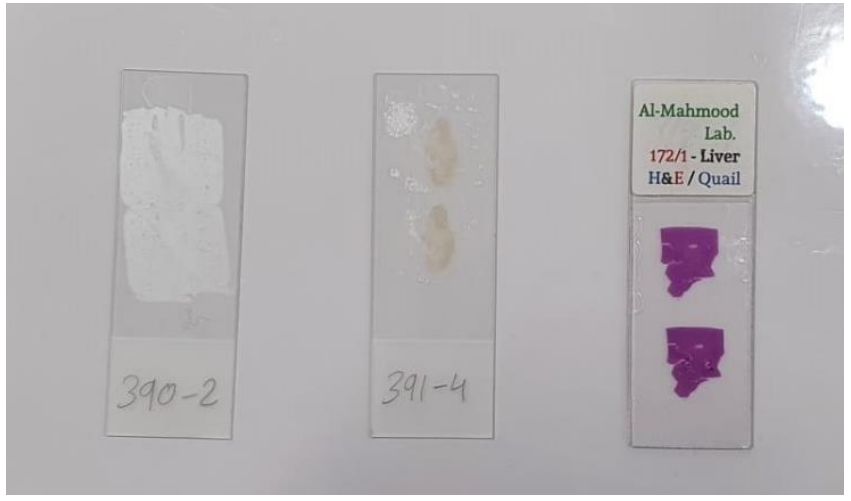

Figure 10: Processing of tissue slides after sectioning until staining, from left, the first slide contain tissue without heat drying, the middle slides shows heat dried tissue, while the first from the left shows stain slide with $H \& E$ stain.

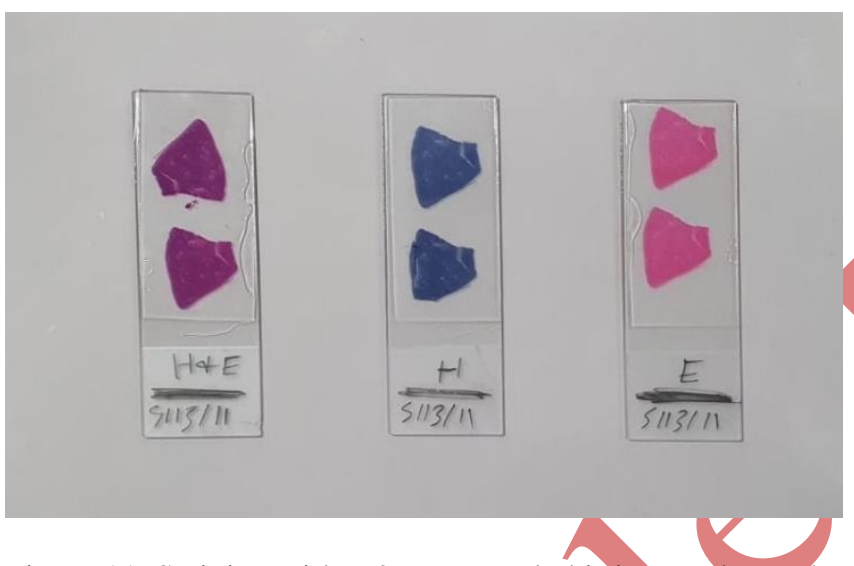

Figure 11: Staining with H\&E protocol, this image shows the differences between H\&E staining, Hematoxylin stain alone and Eosin stain alone.

\section{The general protocol for formalin-fixed paraffin- embedded histopathology}

After receiving the histopathological specimens, samples should be examined carefully with an accurate grossing examination; after that, the representative samples were collected from the site of tissue that show lesions, in addition to the normal tissue to compare between diseased and normal tissues, thickness of these samples should be less than $5 \mathrm{~mm}$ in thickness and should be fit within the cassettes and paraffin mould, later these samples placed in histological cassettes and labelled upon protocol that used by the technician, then these samples immersed in $10 \%$ neutral buffered formalin for at least 72 hours, after that these samples should be washed with running water at least 15 minutes before tissue processing (62). Later the tissue samples were dehydrated using ethyl alcohol starting from $70,80,90$, and $100 \%$ for two changes for one hour to each concentration (63). The samples were then cleared with xylene two changes for 30 minutes each until the tissue had clear yellow to brownish gelatinous appearances (64). Samples were then infiltrated with hot paraffin wax at 58$60^{\circ} \mathrm{C}$ for three changes for one hour at each change, then the samples were embedded using paraffin mould and left to solidify for at least one hour, finally it is ready for sectioning by a rotary microtome (65). Paraffin blocks then sectioned by rotary microtome at $5 \mu \mathrm{m}$ thickness then floated on a hot water bath to remove the folded tissue and creaks the lifted on glass slides then dried using a hot plate at $60^{\circ} \mathrm{C}$ for one hour, then slides being ready to stained with routine hematoxylin and eosin (66).

\section{Conclusion}

We concluded from the current manuscript that the formalin-fixed paraffin-embedded protocol is such a reliable and easy applied protocol, cost efficient, if the technician depends on the logical continuous steps with pure materials would help in getting gain a perfect histopathological slides. Supports the interpretation of the gross lesions that recorded during postmortem examination.

\section{Acknowledgements}

The authors would give their thanks to the College of Veterinary Medicine, University of Mosul, to support their scientific works.

\section{Conflict of interest}

No conflict of interest regarding the publishing of this manuscript.

\section{References}

1. Dada MA, Ansari NA. The postmortem examination in diagnosis. J Clin Pathol. 1996;49(12):965-6. DOI: $10.1136 /$ jep.49.12.965

2. Van den Tweel JG, Taylor CR. A brief history of pathology. Virchows Arch. 2010;457(1):3-10. DOI: 10.1007/s00428-010-0934-4

3. Schultz M. Rudolf Virchow. Emerg Infect Dis. 2008;14(9):1480-1. DOI: $10.3201 /$ eid1409.086672

4. Fye WB. Julius Friedrich Cohnheim. Clin Cardiol. 2002;25(12):575-7. DOI: $10.1002 / \mathrm{clc} .4950251209$

5. Bluth MJ, Bluth MH. Molecular pathology techniques. Clin Lab Med. 2013;33(4):753-72. DOI: 10.1016/j.cll.2013.09.004

6. Al-Ajeli RR, Al-Qadhi AS, Al-Mahmood SS, Alkattan LM. Pathological study of neoplasms surgically excised from animals attended the veterinary teaching hospital. Iraqi J Vet Sci. 2021;35(1): 9-14. DOI: 10.33899/ijvs.2019.126188.1260

7. Al-Mahmood SS. Improving light microscopic detection of collagen by trichrome stain modification. Iraqi J Vet Sci. 2020;34(2): 273-281. DOI: $10.33899 /$ ijvs.2019.126176.1256

8. Al-Mahmood SS, Al-Sabaawy HB. Fasciolosis: grading the histopathological lesions in naturally infected bovine liver in Mosul city. Iraqi J Vet Sci. 2019;33(2): 379-387. DOI: 10.33899/ijvs.2019.125546.1066

9. Al-Mahmood SS, Al-Qadhi AS, Al-Ajeli RR, Alkattan LM. Mixed thymic tumor in a rooster: gross and histological features. Iraqi J Vet Sci. 2019;33(2):201-204. DOI: 10.33899/ijvs.2019.125536.1058 
10. Al-Mahmood SS, Al-Abady SM. Pathological study of subchronic oral toxicity induced by Di (2- ethyl hexyl) phthalate in Japanese quails. Iraqi J Vet Sci. 2017;31(2):67-71. DOI: 10.33899/ijvs.2017.145567

11. Peters SR. Gross examination of tissues in the frozen section room. New York: Springer; 2009. 13-35. DOI: 10.1007/978-1-4419-1234-3_2

12. Schmidt RE. Practical gross pathology. Seminars Avian Exot Pet Med. 2003;12(2):59-61. DOI: 10.1053/saep.2003.127882

13. Vega IE. Labeling pathological tau: An important quest for the unknown. Frontiers Neurosci. 2016;6:10. DOI: 10.3389/fnins.2016.00253

14. Stuart S, Patel PA. Tumour tissue sampling. Imaging Pediat Oncol. 2019;313-22. DOI: $10.1007 / 978-3-030-03777-2 \quad 16$

15. Dail DH. Tissue sampling. Pulmonary Pathol. 1994;12:1-19. DOI: 10.1007/978-1-4757-3935-0_1

16. Hosseini MS, Chan L, Huang W, Wang Y, Hasan D, Rowsell C. On Transferability of histological tissue labels in computational pathology. Lect Not Comput Sci. 2020;35:453-69. DOI: 10.1007/978-3-03058526-6 27

17. Zhou H, Ma S, Song J, Lin Y, Wu Z, Han Z. QR code labeling system for Xueteng-related herbs based on DNA barcode. Chinese Herbal Med. 2019;11(1):52-9. DOI: 10.1016/j.chmed.2018.09.006

18. Al-Mahmood SS, Al-Abady SM. Pathological study of acute oral toxicity induced by plasticizer di (2- ethyl hexyl) phthalate in japanese common quails Coturnix coturnix japanies. Iraqi $\mathrm{J}$ Vet Sci. 2017;31(1):17-24. DOI: 10.33899/ijvs.2017.126714

19. Al-Mahmood SS, Farhan AM, Daoud AS, Hamed OS. Pathological study of liver lesions in cattle slaughtered at Kirkuk province abattoir. Iraqi J Vet Sci. 2017;31(1):7-16. DOI: 10.33899/ijvs.2017.126713

20. Fiette L, Slaoui M, Bauchet A-L. Procedures of necropsy and tissue sampling. Drug Safety Evaluation. Springer New York;2017;71-100. DOI: $10.1007 / 978-1-4939-7172-5 \_3$

21. Cardiff RD, Miller CH, Munn RJ. Limited Mouse Necropsy. Cold Spring Harbor Protocols. Cold Spring Harbor Laboratory;2014 May 1;2014(5):073395-073395. DOI: 10.1101/pdb.prot073395

22. McNeil RJ. Field sampling protocols. Canada: Natural Resources Canada; 2011. 1-10p.

23. Tripathi M. Comparison of Routine Fixation of Tissues with Rapid Tissue Fixation. J Clin Diag Res. 2013;23(3):45-50. DOI: 10.7860/jedr/2013/6233.3754

24. Tripathi M. Comparison of routine fixation of tissues with rapid tissue fixation. J Clin Diag Res. 2013;23(3):23-28. DOI: $10.7860 / \mathrm{jcdr} / 2013 / 6233.3754$

25. Werner M, Chott A, Fabiano A, Battifora H. Effect of Formalin Tissue Fixation and Processing on Immunohistochemistry. The American J Surgical Pathology. Ovid Technologies (Wolters Kluwer Health);2000 Jul;24(7):1016-9. DOI: 10.1097/00000478-200007000-00014

26. Frasquilho SG, Sanchez I, Yoo C, Antunes L, Bellora C, Mathieson W. Do Tissues Fixed in a Non-crosslinking Fixative Require a Dedicated Formalin-free Processor? J Histochemistry \& Cytochemistry. SAGE Publications;2021 May 19;69(6):389-405. DOI: $\underline{10.1369 / 00221554211017859}$

27. Jenkins LL, Burg KJL. Tissue Harvesting and Fixation. Handbook of Histology Methods for Bone and Cartilage. Humana Press;143-58. DOI: 10.1385/1-59259-417-4:143

28. Kwon E, Ryan JD, Bazylak A, Shu LH. Does Visual Fixation Affect Idea Fixation? J Mechanical Design. ASME International;2019 Dec 23;142(3). DOI: $10 / 115 / 1.4045600$

29. Cardiff RD, Miller CH, Munn RJ. Mouse Tissue Fixation. Cold Spring Harbor Protocols. Cold Spring Harbor Laboratory;2014 May 1;2014(5):73403. DOI: $10.1101 /$ pdb.prot073403

30. Rahman MA, Sultana N, Ayman U, Bhakta S, Afrose M, Afrin M, et al. Alcoholic fixation over formalin fixation: A new, safer option for morphologic and molecular analysis of tissues. Saudi J Biological Sciences. Elsevier BV;2021 Aug;DOI: 10.1016/j.sjbs.2021.08.075

31. Titford M. Formalin Fixation. Archives of Pathology \& Laboratory Medicine. Archives of Pathology and Laboratory Medicine;2012 Feb 1;136(2):137-137. DOI: 10.5858/arpa.2011-0363-le
32. Chambettaz F, Marquis-Weible FD, Salathe R-P. Effect of dehydration on optical properties of tissue. Jacques SL, editor. Laser-Tissue Interaction III. SPIE;1992 Aug 7;DOI: 10.1117/12.137483

33. Volynskii NP, Shevchenko SE, Nekhaev AI. Dehydration of ethyl alcohol. Russian J General Chemistry. Pleiades Publishing Ltd;2009 Feb;79(2):326-7. DOI: 10.1134/s1070363209020273

34. Underwood JCE. Essential Histopathology. Histopathology. Wiley;1990 Jul;17(1):98-98. DOI: $\quad 10.1111 / j .1365-$ 2559.1990.tb00676.x

35. Gnus M, Dudek G, Turczyn R, Tórz A, Łacka D, et al. PERVAPORATIVE INVESTIGATION OF ETHYL ALCOHOL DEHYDRATION. Progress on Chemistry and application of Chitin and its Derivatives. Polish Chitin Society;2015 Sep 30;XX:54-63. DOI: 10.15259/pcacd.20.05

36. Cornils B. Lummus ethanol dehydration process. Catalysis from A to Z. Wiley;2020 Apr 18;DOI: 10.1002/9783527809080 cataz10017

37. Smye SW, Hootkins RE, Will EJ. Solute Clearance and Tissue Clearance Times. Seminars in Dialysis. Wiley;2007 Oct 1;11(3):185-8. DOI: $10.1111 / \mathrm{j} .1525-139 x .1998 . t b 00331$.

38. Hyman C, Stone A, Sosnow M. Application of Tissue Clearance Technics in Small Animals. Experimental Biology and Medicine. SAGE Publications;1953 Jul 1;83(3):643-6. DOI: 10.3181/0037972783-20445

39. Lee ES, Lee E. Adyantages of Binaree tissue clearing method. IBRO Reports. Elsevier BV;2019;6:S521. DOI: 10.1016/j.ibror.2019.07.1625

40. Ariel P. A beginner's guide to tissue clearing. The International J Biochemistry \& Cell Biology. Elsevier BV;2017;84:35-9. DOI: 10.1016/j.biocel.2016.12.009

41. hah A, Kulkarni D, Ingale Y, Koshy A, Bhagalia S, Bomble N. Kerosene: Contributing agent to xylene as a clearing agent in tissue processing. $J$ Oral and Maxillofacial Pathology. Medknow;2017;21(3):367. DOI: 10.4103/jomfp.jomfp $14 \quad 15$

42. Buesa RJ, Peshkov MV. Histology without xylene. Annals of Diagnostic Pathology. Elsevier BV;2009 Aug;13(4):246-56. DOI: 10.1016/j.anndiagpath.2008.12.005

43. Metgud R, Astekar M, Soni A, Naik S, Vanishree M. Conventional xylene and xylene-free methods for routine histopathological preparation of tissue sections. Biotechnic \& Histochemistry. Informa UK Limited;2013 Feb 4;88(5):235-41. DOI: 10.3109/10520295.2013.764015

44. Knoblaugh SE, Randolph-Habecker J. Necropsy and Histology. Comparative Anatomy and Histology. Elsevier;2018;23-51. DOI: 10.1016/b978-0-12-802900-8.00003-8

45. Rohlan K, Choudhary S, Kumar V, Shringi N. Embedding Techniques in Tissue Histological Process. Latest Trends in Zoology and Entomology Sciences. AkiNik Publications;2018 Jan 30;38-42. DOI: 10.22271/ed.book02.a04

46. Lim JI, Lim K-J, Choi J-Y, Lee Y-K. Modified paraffin wax for improvement of histological analysis efficiency. Microscopy Research and Technique. Wiley;2010;NA-NA. DOI: 10.1002/jemt.20818

47. Raza G, Iqbal S, Samad Farooq A. Paraffin Wax-Based Thermal Composites. Paraffin - Thermal Energy Storage Applications IntechOpen;2021 Jun 9;DOI: 10.5772/intechopen.97195

48. Dey P. Embedding of Tissue in Histopathology. Basic and Advanced Laboratory Techniques in Histopathology and Cytology. Springer Singapore;2018;29-33. DOI: $10.1007 / 978-981-10-8252-8 \quad 3$

49. Dey P. Processing of Tissue in Histopathology Laboratory. Basic and Advanced Laboratory Techniques in Histopathology and Cytology. Springer Singapore;2018;19-27. DOI: 10.1007/978-981-10-8252-8_2

50. Johnson J, DelGiudice B, Bangari DS, Peterson E, Ulinski G, Ryan S, et al. A Guide to the Location and Orientation of Tissues for Optimal Histological Evaluation. Callis G, editor. CRC Press;2019 Mar 18;DOI: 10.1201/9780429057755

51. Slaoui M, Fiette L. Histopathology Procedures: From Tissue Sampling to Histopathological Evaluation. Drug Safety Evaluation. Humana Press;2010 Sep 30;69-82. DOI: 10.1007/978-1-60761-849-2_4

52. Chapman CM. Troubleshooting in the histology laboratory. J Histotechnology. Informa UK Limited;2019 Jul 3;42(3):137-49. DOI: $\underline{10.1080 / 01478885.2019 .1640923}$ 
53. Breuninger H, Adam P. Embedding and Sectioning. 3D Histology Evaluation of Dermatologic Surgery. Springer London;2013;27-43. DOI: $10.1007 / 978-1-4471-4438-0 \_3$

54. Mohammed F, Arishiya TF, Mohamed S. Microtomes and microtome knives. Annals of Dentistry. Univ. of Malaya;2012 Dec 31;19(2):62-5. DOI: 10.22452/adum.vol19no2.4

55. Titford M. A Short History of Histopathology Technique. J Histotechnology. Informa UK Limited;2006 Jun 1;29(2):99-110. DOI: 10.1179/his.2006.29.2.99

56. Kumar N, Nayak B S, Somayaji SN, Nayak S. Role of Dilute Alcohol in the Removal of Fine Wrinkles from Paraffin Sections, a HistoTechnical Study. International J Morphology. SciELO Agencia Nacional de Investigacion y Desarrollo (ANID);2012;30(1):45-8. DOI: 10.4067/s0717-95022012000100007

57. Alturkistani HA, Tashkandi FM, Mohammedsaleh ZM. Histological Stains: A Literature Review and Case Study. Global J Health Science. Canadian Center of Science and Education;2015 Jun 25;8(3):72. DOI: $10.5539 /$ gjhs.v8n 3 p 72

58. Wittekind D. Traditional staining for routine diagnostic pathology including the role of tannic acid. 1. Value and limitations of the hematoxylin-eosin stain. Biotechnic \& Histochemistry. Informa UK Limited;2003 Oct;78(5):261-70. DOI: 10.1080/10520290310001633725

59. McGavin MD. Factors Affecting Visibility of a Target Tissue in Histologic Sections. Veterinary Pathology. SAGE Publications;2014;51(1):9-27. DOI: 10.1177/0300985813506916

60. Bancroft JD, Layton C. The hematoxylins and eosin. Bancroft's theory and practice of histological techniques. Elsevier; 2019. 126-38. DOI: 10.1016/b978-0-7020-6864-5.00010-4

61. Mohan H. Routine Histopathology Techniques and Staining. Practical Pathology. Jaypee Brothers Medical Publishers (P) Ltd.;2017;7-7. DOI: 10.5005/jp/books/12946 3

62. Sadeghipour A, Babaheidarian P. Making Formalin-Fixed, Paraffin Embedded Blocks. Biobanking. Springer New York;2018 Dec 12;25368. DOI: $10.1007 / 978-1-4939-8935-5 \_22$

63. O'Rourke MB, Padula MP. Analysis of formalin-fixed, paraffinembedded (FFPE) tissue via proteomic techniques and misconceptions of antigen retrieval. BioTechniques. Future Science Ltd,2016 May;60(5):229-38. DOI: 10.2144/000114414

64. Enas S. Mustafa Waseem H. Al-Jameel Saevan S. Al-Mahmood Immunohistochemical detection of P53 and MDM2 and its correlation with histological grading system in ovine pulmonary adenocarcinoma. Iraqi J Vet Sci. 2021;35(4): 687-692. DOI: 10.33899/ijvs.2021.127779.1527

65. Saevan S. Al-Mahmood Asseel M. Rahawi Hadil B. Al-Sabaawy Ahmed M. Farhan Pathological lesions of acute sodium chloride toxicity in common carp: Case report. Iraqi J Vet Sci. 2021;35(3): 417419. DOI: 10.33899/ijvs.2020/126917.1417

66. Yahya KY, Al-Mahmood SS, Al-Hubeity TS. Necropsy findings and histopathological analysis of a terminal stage ewe from a herd with sudden deaths in Mosul. Iraqi J Vet Sci. 2021;35(3):599-604. DOI: 10.33899/ijvs.2020.127015.1435

\section{التقنية القياسية للنسيج المثبت بالقورمالين والمطمور بالشمع: من وجهة نظر الامراضي}

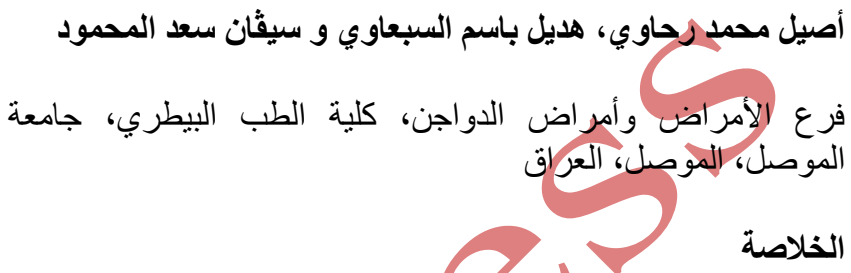

علم أمر اض النسيج بعتبر حجر/الأساس في فهم الأمراض على اضلى

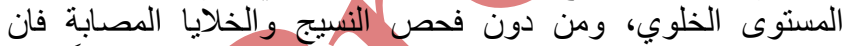

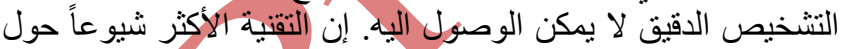

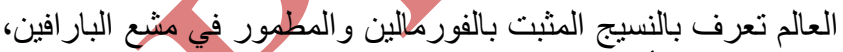

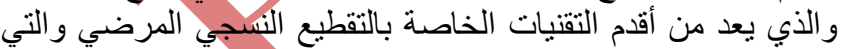

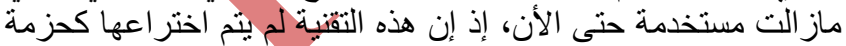

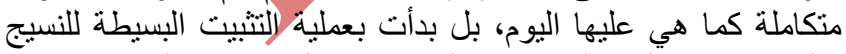

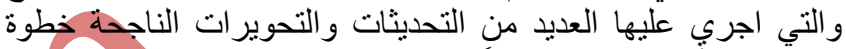

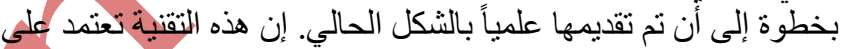

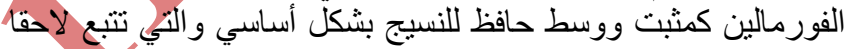

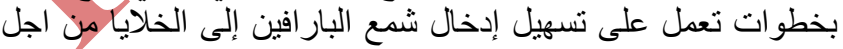

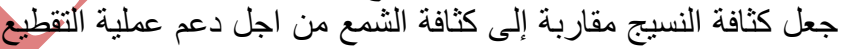

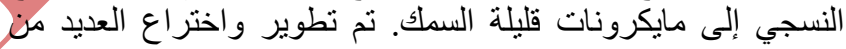

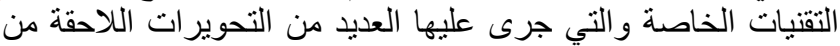

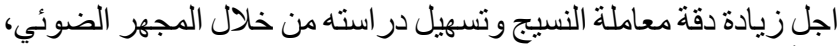

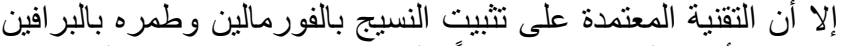

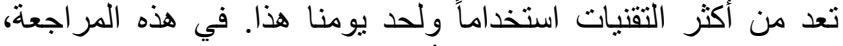

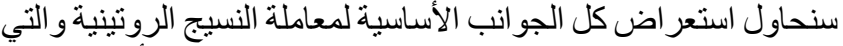

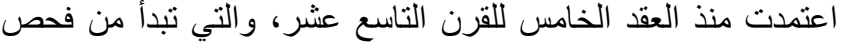

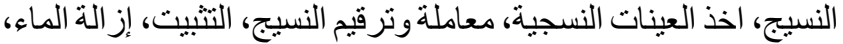
الترويق، التحبيل، و الطمر في شمع البار افين الحار ، كما سنحاول إيضاح التقطيع النسجي الروتيني، فضلا عن التلوين بالملون الكلاسيكي بتقنية ملون هاريس الهيماتوكسيلين والايوسين الكحولي. 